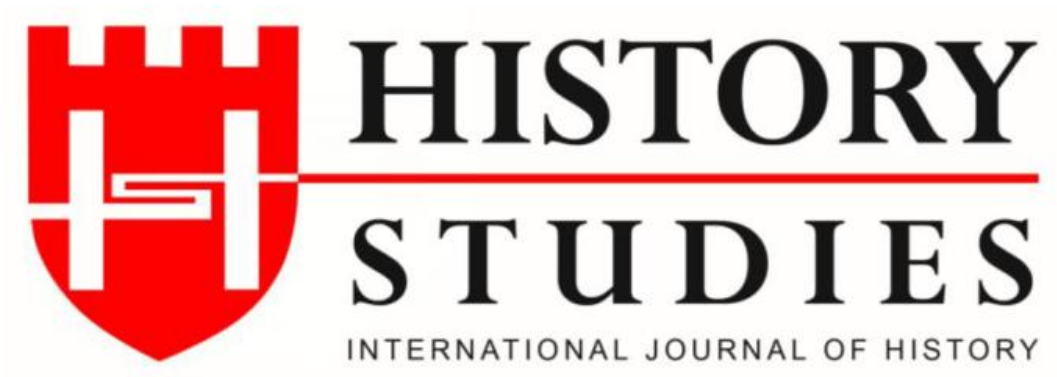

ISSN: 13094173 (Online) 1309 - 4688 (Print)

Volume 11 Issue 1, p. 429-444, February 2019

DOI: $10.9737 /$ hist.2019.724

Makalenin Geliş Tarihi: 20.12.2018 - Kabul Tarihi: 9.01.2019

\title{
The Meetings Between Faisal and Britain about The Sharing of Middle East During The Paris Peace Conference
}

Paris Barış Konferansı Sürecinde Ortadoğu'nun Paylaşımına Dair Faysal - İngiliz Görüşmeleri

\author{
Dr. Resul YAVUZ \\ ORCID No: 0000-0002-7705-1020 \\ Bandırma Onyedi Eylül Üniversitesi İnsan ve Toplum Bilimleri Fakültesi- Balıkesir
}

\begin{abstract}
The developments in the Middle East with the defeat of the Ottoman Empire during the First World War contributed to the political formation of the region. In this study, the diplomatic and political struggles of the political actors who played a leading role in shaping the Middle East were discussed. In addition, as a result of the Paris Peace Conference and the subsequent political negotiations, the search for contacts of the effective people in Arab case, especially Faisal with the national resistance that was under the leadership of Mustafa Kemal in Anatolia was examined and the effects of these works on the British and French authorities were discussed.
\end{abstract}

Keywords: Faisal, Middle East, Britain, France, Paris Peace Conference

Öz: Osmanlı Devleti'nin, Birinci Dünya Savaşı'ndan yenik ayrılmasıly birlikte Ortadoğu'da meydana gelen gelişmelerin bölgenin siyasi şekillenmesine olan katkısı büyük olmuştur. Bu çalı̧̧mada, Ortadoğu'nun şekillenmesine baş rol oynayan siyasi aktörlerin bu süre zarfindaki diplomatik ve siyasi mücadeleleri konu edilmiştir. Ayrıca Paris Barış Konferansı ve sonrasındaki siyasi görüşmeler neticesinde, Araplar açısından ortaya çıkan hayal kırıklı̆̆ı ile başta Faysal olmak üzere Arap davasındaki etkili kişilerin Anadolu'da Mustafa Kemal liderliğinde filizlenmekte olan milli direnişle temas arama çalışmaları ve bu çalışmaların İngiliz ve Fransız yetkililer üzerindeki etkileri de irdelenmiştir.

Anahtar Kelimeler: Faysal, Ortadoğu, İngiltere, Fransa, Paris Barış Konferansı

\section{Introduction}

When the Ottoman Empire was defeated in the First World War as a result of the Armistice of Mondros, a new process that would lead to many changes in the Middle East, including Anatolia, and which would cause serious changes and breaks and political geography, began. Especially during the war, the secret treaties signed by the Allied Powers in order to share the Ottoman Empire were brought back to the agenda again in the sharing Middle East after the war and the involvement of Arabs into this process, the diplomatic maneuvers that would pave the way for a more irreversible structure in the Middle East began $^{1}$.

\footnotetext{
${ }^{1}$ For the contents of the secret treaties signed during the First World War and the implications for the subsequent process of these treaties see Ahmet Hurşit Tolon, Birinci Dünya Savaşı Sirasında Taksim Antlaşmaları ve Sevr'e Giden Yol, AAM, Pbl., Ankara, 2006, pp. 39-86.
} 
When the Paris Peace Conference, which would determine the fate of the Ottoman Empire and the fate of the nations wishing to leave these states, began in January 1919, the Arabs who sworded the Turks with the promises given to them during the war, sent a peace delegation to the peace conference under the leadership of Faisal, the son of Hussein, the Mecca Sheriff. The delegation was assisted by experienced British experts such as Lawrence and Gertrude L. Bell who had prepared for this conference months ago and spent years in the desert with Arabs².

Faisal, who had great hopes, started to prepare for the Council of Ten months ago and was aware of the fact that the greatest supporters of their case were British, and he made statements in leading newspapers of Paris and London to raise public opinion in the European arena. In this process, as Faisal felt the support of the British administration in the establishment of an independent Arab State which he described as their most natural right, he was also aware of the fraction over the region by the revision of the Sykes-Picot Treaty that would allow the French to take a share of the Middle East, would create the region.

In December of 1918, Faisal moved to Europe with his loyalty and hopes for the British in his heart rather than the maps and files concerning the Middle East in his bag. Faisal, in a period of limited but strict instructions given by his father in this process, would negotiate with the people he did not know and have an experience that would shape the fate of his people and of his own against the diplomatic games. This was the first attempt to display in an international platform for Faisal as well as for the whole Arab nation.

\section{First Travel of Faisal to Britain Before Paris Peace Conference}

Faisal and his delegation who would represent Arabian case in such an important platform moved from Beirut to Marseille in the last days of November, first Paris then to London for lobbying. When he arrived at the Port of Marseille on November 26, 1919, Faisal was greeted by Emmanuel Bertrand, a retired foreign ministry official, who had previously been instructed by the French Government to instruct him on how to behave. Because the French government was very disturbed by Faisal's attitude and had plans on Syria from the very beginning. In any case, this discomfort also caused a great tension between the British and the French, as the sharing policies on the Middle East were not shaped according to French interests in the first place. According to them, the Arab interests had to come after the British and French interests in the Middle East. As a result the French government, within the scope of this plan, from the first day of Faisal's visit would show him that distance and blame him about being the person who opened the gap between France and Britain in any environment in Paris ${ }^{3}$. For this reason, Faisal wanted to leave Paris as soon as possible and go to London, but as the French did not want him to engage in lobbying before the start of the conference, they were constantly delaying it on various pretexts. Faisal, however, was extremely annoyed at this, expressing every opportunity to talk about political issues, he asked to be given an appointment with the French President as soon as possible by authorized people ${ }^{4}$.

\footnotetext{
${ }^{2}$ See Gertrude L. Bell's Works and Ideas on the Near and Middle East. Gertrude L. Bell, Mezopotamya'da 19151920 Sivil Yönetimi, Transl. Vedii İlmen, Yaba Pbl., 2004.

${ }^{3}$ Margaret Macmillian, Paris 1919, (1919 Paris Barış Konferansı ve Dünyayı Değişstiren Altı Ayın Hikâyesi), Transl. Belkıs Dişbudak, ODTÜ Pbl., Ankara, 2004, p. 383.

${ }^{4}$ In the following days, the fact that Faysal was not taken care of by authorized politicians and diplomats in Paris caused a reaction in him he stated his reaction to his consultant after a theater Show as: "I did not come here to play and match. If the French think they are going to fool me with their dancers, they are wrong, I want to serve my country.” Ali A. Allawi, Irak Kralı I. Faysal, Transl. Hakan Abacı, Türkiye İş Bankası Pbl., İstanbul, 2016, p. 219,
} 
In fact, Faisal was about to get the support of Britain along with the demands and actions of France during the time he was in Paris. He cared about Britain's negotiations with Paris, accepting their views on Palestine and Mesopotamia, as the beginning of the policy of neutralizing France in the region ${ }^{5}$.

Faisal arrived in London in December after troubled days in Paris. When he arrived London, without his knowledge, Lloyd George was hosting a major debate with Clemenceau, about the main provisions of the Sykes-Picot Treaty. During the talks, the two leaders agreed on the comprehensive amendments to the Sykes-Picot Agreement, signed in 1916. According to this, France would leave the Mosul and Palestinian territories under the dominance of Britain and gain control over all of Syria. This was a new condition and it was a contradiction to the conventions based on the right of Arabs to speak on the Arab lands that were agreed between Sheriff Hussein and McMohan in 1915. Faisal came to London unaware of this consensus that Britain, which he saw as the only ally in the peace conference, would grant France the right of control over Syria ${ }^{6}$. However, in a very short period of time, he began to realise things from the press and the political backstage of London about the intrigues among the Arabs. Thus, in the first meeting with British Foreign Minister Balfour, this situation led to the emergence of an atmosphere full of tensions.

In his meeting with Balfour, Faisal reminded Balfour that the Sheriff family had revolted against the Turks despite the fact that the majority of the Islamic world had been condemned and underlined that the reason for this was the independence assurance given to them by McMohan during the war and the commitments that were expressed in the Seven Declarations ${ }^{7}$. Against these statements of Faisal, Balfour expressed that not the British Government in the war helped Arabs but the Arabs helped the British Government and stated that the British knew that and they would always be friends and help the Arabs. Lord Balfour was a defender at the meeting and although he tried to appease Faisal, Faisal would raise his voice a little bit more, confessing that there were doubts that Britain was the greatest supporter to the Arabs. Although it was known that the Sykes-Picot Treaty would destroy the lives of the Arabs, Faisal said that he could not understand why the British government did not reassure them and stressed that they would not accept any invasion in the region on the basis of this treaty. Faisal continued as follows and told Balfour, "If you don't help us, we will declare your treacherous activities and fight against anyone who wants to occupy our lands" and he would demand the British government to tear this sinister treaty with France. Against the oppositons of Faisal, Balfour promised Faisal the honor to provide for this by expressing that the Arabs would come out with a face smiling with glory and honor as they had hoped at the peace conference. On the next day, Faisal met King George V in Buckingham Palace and was given

\footnotetext{
${ }^{5}$ Mehmet Derviş Kılınçkaya, Arap Milliyetçiliği ve Milli Mücadele’de Türkiye-Suriye İlişkileri (30 Ekim 1918-21 Теттиz 1921), (Unpublished doctoral thesis), Hacettepe Üniversitesi, Atatürk İlke ve İnkılâpları Enstitüsü, Ankara, 1992, p. 121.

${ }^{6}$ As a matter of fact, in the hours when Faysal went to London, there was a consensus among the representatives of the British Government that keeping the promises given to the Arabs during the war. Curzon, in particular, wanted the promises given to the Arabs to be fulfilled. Mim Kemal Öke, Siyonizm ve Filistin Sorunu (1880-1923), 2nd Ed, Kırmızıkedi Pbl., İstanbul, 2011, p. 314.

${ }^{7}$ A statement by the British Government in June 1918 addressed to seven Arab leaders. In the statement, the British Government accepted the seven leaders as leaders of the Arabs who had sovereignty and independence before the war and, who were living in areas taken from Turks during the war. In addition, according to the declaration, these regions were to be managed on the basis of the Self-Determination principle, which was expressed in the Wilson Principles. Paul C. Helmreich, Sevr Entrikaları, Büyük Güçler, Maşalar, Gizli Antlaşmalar ve Türkiye'nin Taksimi, Transl. Şerif Erol, Sabah Pbl., İstanbul, 1996, p. 5; See also. Mehmet Davulcu, Faysal Döneminde Türkiye-Suriye İlişkileri (1918-1920), (Unpublished master thesis) Ankara Üniversitesi, Türk İnkılap Tarihi Enstitüsü, Ankara, 2007, p. 82.
} 
the Royal Order of Victoria as a mark of the common blood that the Arabs and British were fighting side-by-side in the battlefield. In this meeting King George V. would try to assure Faisal about support and the loyalty of the Britain to the Arab case ${ }^{8}$.

During his stay in London, Faisal would continue his close contacts with British officials, and to continue support tours before the conference. For this purpose, he had a private meeting with Lord Curzon at his home. In the meeting in which Faisal stated that it was very important, Curzon reaffirmed Brtain's support for the Arabs and did not neglect to ask Faysal for a more detailed note about Arab demands. Curzon would also have asked for a memorandum to indicate the Arab demands to be presented to the peace conference from Faisal by means of the support of relevant aid channels. Faisal, leaving quite satisfied in the meeting, told Curzon that they did not want to give anything to a French except a symbolic presence in Syria and expressed that they would do this only for the loyalty to the Britain. Faisal was very hopeful about the negotiations in London compared to the meetings with French officials in Paris. The fact that he heard such clear support from Britain which he called as their greatest ally about their historical case, gave him moral and courage before the conference. In fact, with this moral and courage Faisal held high-level contacts with Zionist officials during his stay in London and he would even say that he would allow partial Jewish immigration on Palestinian territory under the condition of support for the Arab case. ${ }^{9}$. Of course, these words would cause Faisal to suffer, Faisal would now follow a politics that tended to give every promise to get the support of the Zionists in their case ${ }^{10}$.

\section{Faisal, At The Council of Ten}

These contacts with the Britain's top political officials in London before the Council of Ten seemed to have fulfilled the morale of Faisal. In fact, he was acting on the instructions he received from his father, Sheriff Hussein ${ }^{11}$. This would be reflected in all of Faisal's behaviors and speeches at every stage of the conference. Sheriff Hussein made Faisal feel that Britain was the biggest supporter of their case. Father Hussein had summarized this situation in a moral telegram to Faisal before the conference started as follows:

"...Since our policy is based solely on cooperation with Britain, and we do not cooperate with any country, then you will meet all the British Delegates and other important British people and the British Statesmen who will want to embrace you at the conference. Again, you will follow the directives they will give you in your studies and general speeches at the conference and any other place."12

About 3 weeks after the start of the peace conference, Faisal was invited to present all aspects of the Arab Case in person before the Council of Ten which was considered as decision-making mechanism, on 6 February ${ }^{13}$. In fact Lord Curzon who knew that Faisal had

\footnotetext{
${ }^{8}$ Allawi, ibid., s. 225.

${ }^{9}$ For this purpose, despite the reactions of his assistants, in a meeting between the Zionist movement leaders Weizmann and Faisal the implementation of the Balfour Declaration in favor of the Jews, allowing the Jews to migrate to Palestine were discussed and even an agreement was signed. Faisal, however, did not neglect to make an annotation that the agreement agreed upon with Weizmann would be out of date if a small change and correction was made in the promises given to them by Britain on the condition that these conditions would be fulfilled, only "... if the Arabs gained their independence, they would agree with the text..." George Antonius, The Arap Awekening, Khayet's College Book Cooperative, Beyrut, 1989, p. 439.

${ }^{10}$ For detailed information see Öke, ibid., pp. 311-330.

${ }^{11}$ Kilınçkaya, ibid., p. 123.

${ }^{12}$ Laurance Evans, Türkiye'nin Parçalanması ve ABD Politikaları (1914-1924), Örgün Pbl., İstanbul, 2003, p. 119.

${ }^{13}$ In the Arab delegation which was formed under the chairmanship of Faisal, people such as Rüstem Haydar, Faiz el-Hüseyin, Ahmet Kadri and his brother Tahsin Kadri, who were defending the Arab unity and independence,
} 
been invited, asked Faisal to prepare a memorandum in order to uncover the outline of their case, in this preparation, many British officials, including Lawrence, provided assistance. On 1st January 1919, the memorandum had been distributed to the political representatives of the states that formed the Council of Ten before the prepared memorandum was read in front of the council. A summary of the memorandum was presented to the conference on 29 January ${ }^{14}$. While preparing this memorandum, Faisal had taken into consideration of British, French and Zionists' ambitions and plans over the Middle East ${ }^{15}$. On 6th of February, Faisal who made a change on the memorandum the day before the conference, made the final form of the speech that he would make in front of the Council with his advisors ${ }^{16}$.

On the 6th of February, representing the beginning of the Arabs' appearance on the international stage in the 20th century, Faisal, along with Lawrence who would translate the speech into English in front of the couincil and his counselors, moved to Quaidlar Orsay where the council was gathered Faisal was greeted at the door by Clemanceau and was presented to the leaders. After Clemanceau's saying, "The floor is Emirate Faisal's", Faisal started to address the great leaders who were there to reshape the world ${ }^{17}$.

Faisal, whose speech was translated into both English and French at the same time, began his speech, which he described as the fundamentals of the Arab case and was previously presented to council members on January 29, by expressing that he came as a representative of his father with the aim of defending their case. Faisal requested accepting Arab Nation as dominant in the geography that formed the continent of Asia, extending from the line that passed from İskenderun to Diyarbakır in the north and in the south to the Indian Ocean and emphasized the importance of acceptance by the League of Nations. He repeated the reasons why they were dominant people in the region in order to strengthen his claims in his speech. Faisal mentioned that as the regions in Arab Asian geography including Syria, Iraq, Jazeera, Hijaz, Najd and Yemen, were different economically and socially, it was necessary to be under domination of different Arab governments rather than being under the domination of the same country. Faysal, who addressed Syria in most of his speech, said that a sovereign Syria needed foreign aid to grow in terms of agriculture and industry, and emphasized that it was essential that the state, which would provide this assistance, to contribute in cash. Regarding the Hejaz region, he stated that the administration had to be in patriarchial conditions in that region where tribal life was effective and that they preferred such management to European style management because of the social conditions of the region. Although British authorities didnot want, Faisal who had special part about Palestine in his speech added that Arab population in the region was the majority and they could live with the Jews who were very close to them as a race and there was no conflicting character between the two races. He continued his speech as

would be appointed. Avni Abdülhadi and Cemil Merdam were included in the delegation in Paris. After a while, Avni Abdülhadi would serve as general secretary of the delegation. However, Rüstem Haydar, with Emirate Faisal, would participate in the conference as an official representative. Ömer Osman Umar, Osmanlı Yönetimi ve Fransız Manda Idaresi Altında Suriye (1908-1938), AAM Pbl., Ankara, 2004, p. 401. Lawrance, who helped the Arab Delegation to prepare for Faysal's speeches and to hold talks with some senior people during his stay in Europe, would have contributed significantly if not officially. Allawi, ibid., p. 22.

${ }^{14}$ FO. 608/92, No: 1551, 29 January 1919.

${ }^{15}$ Kılınçkaya, ibid., p. 122.

${ }^{16}$ Faisal was told by representatives of the Allied Powers that he would speak before the Council. However, Faysal and his advisors had great uneasiness as the day and time of the speech was announced to him on February 5th. That night, Faisal, with his advisors, prepared a speech text based on the principles of memorandum for the allied leaders. Rüstem Haydar, one of his advisors, stated that Faisal was very restless all night because he understood the seriousness of the situation. Rüstem Haydar, Mudhakarrat Rüstem Haydar, ed. Nejat Fathi Safwat, Al Dar alArabiyalil Mawsou'at Beyrut, 1988, p. 233.

${ }^{17}$ Allawi, ibid., s. 247. 
"The Allied States promised freedom to Arab nation at the end of the war" and emphasized that the Allied states had to keep their promises according to their victory over the war. Faisal completed his long, fluent and impressive speech by looking at the representatives of the big states of the board as follows, "....We would like to express our gratitude to you for your contributions by your experiences, not by imposing civilization on us" 18 .

Lloyd George and other Allied leaders listened to Faisal with great interest, while Clemenceau and Foreign Minister Pichon were extremely displeased ${ }^{19}$. After the speech, Lloyd Geoerge asked Faisal some questions about the situation of Iraq, and Wilson asked several questions to learn the attitude of the Arab people towards the mandate in accordance with the Council of Nations ${ }^{20}$. In fact, Wilson's question was not an ordinary question. It was about to investigate the suitability of an international commission intended to be sent in order to learn about the tendency of the people in Syria that Faisal would dwell on and make diplomatic contacts for realization afterwards ${ }^{21}$.

Faisal was not the only person who spoke in front of the council about the Syrian and Arab case. On February 13, Dr. Howard Bliss, President of the Syrian Protestant College in Beirut, made a speech in which he made an appeal to send an international investigation commission to Syria. In fact, Bliss who wrote to American Delegation in Paris told that if the people of Syria were listened to, the people would first choose the United States and then the Britain $^{22}$.

Both Faysal's and Bliss's speeches supporting the Arab independence movement in front of the council seemed to disturb many French people, especially Clemanceau. France immediately made a counter-move to show that Faisal's claims were not correct, on the day that Bliss addressed the council, they would have summoned the President of the Syrian Central Committee of Syria, Shukri Ganem, who was a French citizen of Syrian origin living outside Syria for 40 years, to appeal to the high council members. Faysal was opposed by saying that Ganem had been invited by some other people, but the speech of Ganem that was based on unfounded claims disturbed many people, especially Wilson. As expected, this was a person sent by French intelligence in order to deactivate Faisal on Syria ${ }^{23}$. This tactic disturbed Faisal so much, Faisal, wrote a letter his brother Zayd, in Damascus, immediately, and asked Syrian notables to send a telegram to the peace conference telling that they had chosen him as the Syrian people's representative. As a result, at the request of Faysal, after a short time,

\footnotetext{
${ }^{18}$ As for the speech, several rumors have been put forward that Faysal only read the verses from the Qur'an in front of the council and that Lawrance has completely translated the text into the board according to his thoughts. Macmillian, ibid., p. 383; These claims, which were sourced from French origin and intended to humiliate Faisal, were criticized violently in the memoirs written by their advisors and it was stated that this was purposeful. Allawi, ibid., p. 249.

${ }^{19}$ As for the speech, several rumors have been put forward that Faysal only read the verses from the Qur'an in front of the council and that Lawrance has completely translated the text into the board according to his thoughts. Macmillian, ibid., p. 383; These claims, which were sourced from French origin and intended to humiliate Faisal, were criticized violently in the memoirs written by their advisors and it was stated that this was purposeful. Allawi, ibid., p. 249.

${ }^{20}$ Evans, ibid., p. 129.

${ }^{21}$ FO. 608/92, No: 13156, 5 June 1919.

${ }^{22}$ Umar, ibid., p. 402.

${ }^{23}$ Haydar, ibid., p. 146.
} 
support telegrams from the Arab committees, in many parts of the world, especially in Syria, would start to be delivered ${ }^{24}$.

Faisal's speech at the high council, full of fiery words about the Arab case, would soon begin to echo in the European press and the Middle East Immediately after Faysal's speech, Sheriff Hussein congratulated Faisal that he had done the right thing for his country in a telegram he sent on February $10^{25}$. Faysal, in a telegram about the political situation in the conference and the French claims on Syria, mentioned that his speech had a good effect on the members of the committee and he wanted independence for all Arab lands. In the telegram Faisal also expressed that he was hoping to win, however, complaining that a propaganda against them was being launched particularly by the French press and that the French government had done nothing against that ${ }^{26}$.

In fact, the issue that Faysal complained about in his telegrams were quite painful for the Arab delegation in Paris. As if the French press had spoken unanimously, they commented on condescending views of Faisal and that the grounds of the Arab case in Syria were not based on solid foundations. In an article in which Faysal's speech was evaluated in the Temps newspaper, it was emphasized that the claims made by Faisal for the Arab lands and Syria were unfounded, and that France was the protector of Syria. In the newspaper's review, it was said that those who tried to prevent this would mean aiming to bring Britain and France encounter in the region ${ }^{27}$. The Gaulois newspaper described Faisal as a fiery and intelligent agent, while the Demoratic Nouvelle newspaper described Faisal as a very greedy man. In addition, the Pays newspaper commented that it was against the logic of the council to take the Syrian issue on the agenda instead of the German issue ${ }^{28}$. This situation of Faisal also disturbed the other members of the Hijaz delegation in Paris. In fact, Emirate Faisal remembered the words of his father that no one else would help them in this case, except the British. During his stay in Paris, he would continue solidarity with the British authorities in any environment. In this period, when the French press was very angry to Faisal and his case, he himself sent a letter to the British delegates in Paris, demanding that the Arab memorandum presented to the council be taken into account and that the British press had to take action about publishing the news ${ }^{29}$.

Faisal succeeded in influencing many people outside of the French although the criticism of the French press was based on who would be influential in Syria, and who would accept it at first. Lloyd George, who wrote the memoirs about the conference after many years, would express his contention in a mundane, concise and dignified manner in favorable terms by including Faisal's impressive speech in that day ${ }^{30}$. Similarly, USA Secretary of State and USA representative, Robet Lansing also described Faisal as someone who was committed to convincing everyone that the Arabs would bring peace to the region. Although Lansing expressed this in his memoir, Faisal's speech in front of the high council had a positive effect

\footnotetext{
${ }^{24}$ Moreover the support telegrams and messages became so intense that in a note from British intelligence in Cairo it was stated that the tribal chiefs, from Syria, Yemen, Hejaz, and Duka, accepted Faisal as the only representative in Paris by taking the oath of allegiance Sheriff Hussein. FO. 608/92, No: 6816, 5 March 1919.

${ }^{25}$ FO. 608/92, No: 2235, 10 February 1919.

${ }^{26}$ FO. 608/92, No: 2478, "A telegram from Faisal to Sheriff Hussein and Zeid," 20 February 1919.

${ }^{27}$ FO. 608/92, No: 1694, "Report on the reaction of the French press to Faisal's speech from Lord Dery to Lord Curzon”, 8 February 1919.

${ }^{28}$ FO. 608/92, No: 1670, 8 February 1919.

${ }^{29}$ FO .608/92, No: 1988, 12 February 1919.

${ }^{30}$ David Lloyd George, Memoirs Of The Peace Conferance, Cilt. II, Yale University Press, New Haven, 1939, p. 673.
} 
on Wilson. This effect would undoubtedly give a great impetus to the work of sending an international commission to the Syria as soon as possible in the same month ${ }^{31}$.

\section{International Commıssion Decision For Syria And Contacts of Faisal}

Faisal continued to stay in Paris for a while in order to determine the of the political developments after his speech before the High Council and to lobby for Syria in Paris ${ }^{32}$. During this period, Faisal wanted to see the position of Britain and the USA in Syria. In fact, according to the lobby and the information Lawrence quoted Britain was still a unique supporter of the Arab case. However, Faisal was extremely uncomfortable with the British and French talks that took place behind closed doors. As a matter of fact, in a day when Faisal was visiting Germany and Belgium, a meeting was held in Lloyd George's office in Paris on 20 March, where Lloyd George, Clemanceau and Wilson attended and the main subject was Syria. General Allenby, who was in Syria, was invited to the meeting. Allenby was the person who knew the effects of the recent developments in Paris on Syria and that's why he was invited for the meeting. And he transferred these ideas to Lloyd George. The meeting, as expected, was marked by tension between British and French on Syria, with Wilson's suggestion, the issue of sending international commissions to the Near East was brought to the agenda in order to find out the public's tendency. In fact, that was the only decision that came out of the Allied meeting that day ${ }^{33}$. This seemed to strengthen Faisal against France. Because almost everyone knew that the Syrian people would not prefer France in a possible mandatory plebiscite. The decision of sending a commission to Syria seemed to please Faisal, he shared this happy news immediately with the Arab committees around the world (Bueros Aires, New York, Saint Paulo, Committees in Boston) by saying, " the fate of the Arab Nation is now in the hands of the Commission ",34.

Faisal considered the future of the Arab lands quite dark under possible French colonialism. According to him leaving the Syrian Region to the French Administration would not be sufficient for Syria's security and development. Because it meant that along with Algerian example, economic collapse of that administration could not add much to the country. Therefore, if Faisal would be a protector of their own, it should be a state that would enable the Arabs to develop and give them their freedom. Undoubtly, this state had to be Britain ${ }^{35}$. Despite all these wishes and desires, the Paris Conference and its subsequent diplomatic games caused Faisal not to get exactly what he wanted and this would lead to their national struggle against a French administration under the mandate of the League of Nations in Syria ${ }^{36}$. At this point, Faisal would make diplomatic maneuvers to take the USA support in Paris, at least in favor of a positive view of the Arab case, and to have the opportunity to transfer the Arab case

\footnotetext{
${ }^{31}$ Robert Lansing, The Big Four and Others Of The Peace Conferance, Hutchinton, Londra, 1922, p. 162; Although Faisal's speech in front of the Council of Ten affected many people, in fact, Faisal was faced with many obstacles at the peace conference in Paris. The fact that he lacked the experience of diplomacy, including the lack of Arabicspeaking translators, was particularly challenging in explaining his case to the Allied chiefs. Öke, ibid., p. 315.

${ }^{32}$ In fact, Faisal intended to call his brother Abdullah instead, and to return to Syria. Because in the absence of Faisal, groups opposed to Faisal in Damascus had accelerated their propaganda work. And this seriously threatened Faisal's position. Although Faisal wrote to British Government to get permission to leave, the British would have asked Faysal to postpone it for at least 10 more days with the concern that this separation could be a problem for the French However, as a result of the developments occurred, the unexpected interview traffic that emerged with the diplomacy Faisal would not return to Damascus at the end of this period FO. 608/92, No: 2283, 17 February 1919.

${ }_{33}$ Öke, ibid., p. 318.

${ }^{34}$ FO. 608/92, No: 5700, 29 March 1919.

${ }^{35}$ Evans, ibid., pp. 121.

${ }^{36}$ For the struggle against the French in Syria, see Murat Güztoklusu, Özdemir Bey'in Filistin-Suriye Kuvva-i Milliyesi ve Elcezire Konfederasyonu, Bengi Pbl., İstanbul, 2010; Umar, ibid., pp. 349-446.
} 
to Wilson and many American diplomats face-to-face. In his letter to his brother Zayd, Faisal explained this key role of America as follow:

"I accepted to meet key persons and I will meet President Wilson individually as sson as possible and I hope to come to a conclusion. I'm going to remind him of the plan I've declared, in other words, I would remind to get the public opinion I mean a plebiscite will be made in all the lands rescued from the Turks and that there is no doubt that he will accept this. $" 37$

Faisal wasn't comfortable in spite of these contacts with the Americans. As he left Paris to return to Damascus on April 21, he worried that the British would turn him over and come to an agreement with France any time In spite of all his contacts with the British authorities during his stay in Paris, he had not been able to persuade them to stay in Syria. Not only Faisal but the whole Arab delegation, could see such a result from this political air in Paris. Britain was trying to prepare for the withdrawal of Syrian troops by revision of the Sykes Picot Treaty signed with France in 1916. This would mean the end of Faysal against France in the Syrian case. When Faisal arrived Damascus with a glorious ceremony in such a uncertain polticial environment and a great dissappointment against British, Faisal had hopes about the works of an American-Supported international commission.

\section{Syrian General Congress and The Report of Kuing-Crane Commission}

Immediately after his return to Damascus, Faisal held talks with opinion leaders and tribal leaders from various parts of the geography. The main purpose of these talks was to understand whether the public's political support to Faisal continued. However, Faisal did not only have contacts with the Arab notables in Damascus. He would hold a series of meetings with British and French generals and statesmen to announce to London and Paris his voice from Damascus. For this purpose, Faisal met with Clayton on May 12. In the details of the conversation between Faisal and Clayton, that was sent to Lord Curzon, Faisal asked if the peace conference offered mandate to Britain oven Syria, whether Britain's answer to this proposal would be positive. Clayton responded as "I don't know" but Faisal expressed that he would ask for the independence of Syria at the conference and stated that there was a full consensus among Arab delegation about this issue. Faisal also said he had heard that some British troops had left their positions to the French, but Clayton would try to deny that information, saying it was not true. Clayton, in relation to the impressions he obtained from this interview, told Curzon that Faisal began to nurse a grudge towards France and if Syria was left to France or if they were given a mandate to Syria, Faysal would eventually declare that he would fight against the French. Clayton, who sent a copy of the long interview details to the British foreign affairs and war ministry, would state in a report to the British Government that it was essential to give a response to Faisal's request to support independence in Syria ${ }^{38}$.

In fact, after returning to Damascus, Faisal had entered into many different formations independent of the British. Since the first day he came, he had meetings with the leaders tribes and the nobles from many parts of Syria and the Hijaz. The most important issue dealt with in these meetings was, of course, the proclamation of the independence of Syria. Although Faysal knew that Britain would react to it, the most important stage in the process that would lead to Syria's independence would be to accelerate efforts to convene a national congress. Eventually, on June 3, 1919, Syrian Congress was held in Damascus with the participationg of the

\footnotetext{
${ }^{37}$ Allawi, ibid., p. 245.

${ }^{38}$ FO. 608/92, No: 10304, 10466, “From British Forces Command to Lord Curzon”, 14 May 1919.
} 
delegates that were elected by two levels election system in different parts of Syria ${ }^{39}$. This would be interpreted as an open challenge by the Allies, primarily France. The congress that coincided with the period when the King-Crane Commission was preparing to work in Syria, it aimed to look at Allies', particulary Britain's Syrian issue from a different perspective, with their work and demands. So that the investigation commission report that was prepared as a result of the works in June and July in Syria, it was decided about the protection of the unity of Syria, including Palestine, the granting of autonomy to Lebanon within the united Syria, and constitutional monarchy administration in Syria and bringing Faisal as a king to the Syrian Kingdom. It was thus noted that the people were ready to adopt a regime in a democratic way, such as a parliamentary kingdom. In its report, the Commission also opposed the idea of placing any part of Syria under the French mandate, suggesting USA mandate on Syria and Britain on Iraq. In the continuation of the report, if the USA didnot accept the Syrian mandate, it was demanded that the mandate in the region be given to the Britain ${ }^{40}$. It was also stated that no matter which satet was amandater, it had to use its Powers not as a colonial power, but as a protector who considered the development and salvation of the region as a sacred duty. The Commission, which made some evaluations regarding the Zionist claims in Palestine, would point out that strictly limiting the Zionist claims in this region and, consequently, the adoption of the Balfour Declaration was important for the peace of the region ${ }^{41}$.

\section{Britain's Decision of Withdrawal From Syria And The Reflection of This to The} Faisal-British Meetings

After the long negotiations of Britain with the French, the first signs of political and military change in the Near East and the Caucasus were seen with the withdrawal of British troops from Armenia and the Caucasus. Then as agreed between Lloyd George and Clemanceau on September 13, 1919 - that Emir Faisal went mad - and in a consensus aimed at putting Syria under the French mandate, withdraw of the British armies from Syria and Cilicia in favor of France. According to the agreement, which would take effect on November 1, the French forces would replace the British forces on the beaches of Cilicia and Syria, and Faisal government forces would pass to the cities of Damascus, Hama, Homs, and Aleppo ${ }^{42}$. Thus, the region on the east of the Sykes-Picot line would be given to the Arabs and the region on the west would be given to the French. Until the final border between Palestine and Syria was determined, the outposts on the border lengths would be in the hands of the British in accordance with the limits they demanded. It was also agreed that, upon the insistence of Clemanceau, Faysal would be informed of the treaty as soon as possible, and that the half of the payment given to the Faysal by the British on a regular basis was then paid by France. Thus, on the French front, all military and political dominance in Syria and Cilicia was passed

\footnotetext{
${ }^{39}$ FO. 608/92, No: 13156, 5 June 1919.

${ }^{40}$ The King-Crane Commission presented its report to the American delegation in Paris in August 1919. However, the report was kept for three years. It was not published until December 1922, that the actual division of the Near East was registered. Allawi, ibid., p. 302; Öke, ibid., p. 321; When report first published in Editor and Publisher in New York Editor William T. Ellis in the foreword to the Allies commented that if this report was published in time, the map of the Middle East could have been drawn in a different way. Öke, ibid., p. 322; In the report it was also stated about the seperation of Turkey into regions and establishing mandate administration in those regions and leaving those administrations to the USA.For detailed information see. Ali Karakaya, Milli Mücadele'de Manda Sorunu ve Harbold ve King-Crane Heyetleri, Başkent Pbl., Ankara, 2001.

${ }^{41}$ Öke, ibid., p. 320.

${ }^{42}$ Allawi, ibid., p. 303; This agreement, referred to as the Syrian Agreement, was brought to the attention of the Allies at the meeting of the Council of the United States, attended by US Secretary of State L. Polk, British Prime Minister Lloyd George, French Prime Minister Clemenceau, Italian Foreign Minister B. Tomaso and Japan Representative B. Matsal. For detailed information about Syrian Agreement see. Umar, ibid., pp. 376-378.
} 
from the British to the French, with this agreement that was considered as a complete diplomatic victory ${ }^{43}$.

Faisal was not aware of this bilateral meeting in Paris, behind closed doors about the future of Arab lands. But Faisal could see something underneath unstable attitudes that became increasingly evident in British authorities. There was no doubt that the atmosphere of unrest in Anatolia, the Caucasus, and the Near East was at the beginning of the reasons that led them to such instability and Britain couldnot see the power that would settle this turmoil. Moreover, the rising economic bill was another dimension of the problem. Therefore, there were serious economic reasons for the withdrawal from the Caucasus and Syria, -even if it was not disclosed to the public ${ }^{44}$.

As a result, although Faysal did not intuit the decision of Britain to withdraw from Syria, he was very disturbed that the British government, like the US government, had uncertainty in its decision to establish mandate on the Syrian and Arab territories. But upon the news of such a consensus between Lloyd George and Clemanceau, he was urgently invited to London, where the issue of the future of Syria, especially in the eyes of the Arabs, became uncertain with worries and contradictions. In particular, Lloyd George wanted Faisal to arrive in Paris in an urgent telegram sent to Colonel Richard Meinertzhagen, who was appointed to replace General Clayton in Cairo, to avoid further uncertainity ${ }^{45}$.

Faisal, who was welcomed by a very low-level delegation by the French when he arrived in Marseille, was put on a train to London without being allowed to cross over to Paris. The French did not want Faisal to stay longer on French territory. They assigned the British Government, especially Lloyd George, to explain the decision about Syria with the British to Faisal $^{46}$. Faisal realized the truth in the port of Marseille. In a letter to his brother Zaid on the way to London, he expressed his reaction to the fact that the French were dispatching troops to Syria as required by the treaty with the British as follows, "God forbid, I will immediately return and declare my opposition, you must declare the independence of the country and start taking troops for defense ${ }^{47}$.

As soon as Faisal arrived in London after a long and strenuous journey, on September 18, he immediately held a series of meetings with senior British officials. Then on September 19, he met Lloyd George at the prime minister's office. At the meeting which was very important for both sides Lord Curzon, Commander of the House of Commons Bonar Law, Marshal Allenby, and the Egyptian Expeditionary Military Officer Colonel Cornwallis were present. First, Lloyd George explained to Faisal that the reason for his invitation was to persuade about the acceptance of the proposal of France on invasion of Syria and tried to explain the reasons

\footnotetext{
${ }^{43}$ In fact, this treaty signed between Clemanceau and Lloyd George, before the ink was dried, appealed by some people in Europe and America about the healthy operation of the agreed principles. The most important one was the report by Captain William Yale, who was a member of the King-Crane Commission, on 21 October. Yale stated in his report that the Arabs would not accept this treaty, the frictions between the French troops and the coastal parts of Syria, the Arabs, would create serious dangers for the Catholics living in the region. Yale also warned that this loneliness from the West could lead the Faisal and Arabs to act together with the Turks, and that Allies in the Near East could cause them to re-enter the conflict. Helmreich, ibid., p. 108.

${ }^{44}$ Helmreich, ibid., pp. 98-102.

${ }^{45}$ In a telegram sent by the Prime Minister himself, Lloyd George said that he would stay in Paris until next Tuesday, and Emirate Faisal would soon arrive in Paris with regard to the Syrian issue, if if he could not get there, and to meet with him in London. FO. 608/92, No: 18804, 8 September 1919.

${ }^{46}$ The British Government, however, gave such importance to Faisal's trip to Europe that he had instructed all British representatives to accompany Emirate Faysal on his way to quickly and safely arrive in London. FO. 608/92, No: 15461, 16 September 1919.

${ }^{47}$ İbid., p. 305.
} 
why Britain decided to withdraw its forces in Syria while keeping its power in Mesopotamia and Palestine. However, Faisal objected to this immediately and expressed how important British armies remain in Syria in terms of peace and tranquility in the region. Faisal's resentment and anger were reflected in his words so much that he told Lloyd George that the European states wanted Muslims to come out and declare war to the caliph, but he said that he saw the European countries aim was to divide the Arab lands but he could not explain this betrayal to his nation ${ }^{48}$. But even these angry words wouldn't take Lloyd George back from the agreement with Clemanceau. Two days after this meeting, Faisal submitted Lloyd George to send a memorandum to the immediate annulment of the British-French consensus based on the division of the Syrian territory and which was contrary to the League of Nations treaty ${ }^{49}$.

Faisal continued his persistent and result-oriented talks with the British Government. On September 23, he met with Lloyd George at the office of the Prime Minister. At the meeting that Lord Curzon was also present Faisal brought a reconciliation signed between his father, Sharif Hussein and McMohan during the war, which he saw as a very powerful lever. Lloyd George and Curzon, however, stated that these documents, which consisted of mutual correspondence and which the British did not sign in any way, could not be regarded as a treaty. ${ }^{50}$ This meant the collapse of the main points in Syria case for Faisal and he could not hide his disappointment about it. Faisal realized that many things had changed for themselves in London. On September 26, he wrote a long letter to his father, evaluating the developments so far and the British perspective on Syria. Faisal advised that they had to do something against the changing politics in the letter, asked to resolve th problems between the tribal chiefs and the sheikhs and take action to make new alliances. Faisal who was anxious bout the developments wrote a letter to his brother Zeyd "By God, By god power! And power! If we can show our power and our influence in terms of military, the The Allied Powers will give us so much respect and accept our demand ${ }^{51}$. Faisal could see the aspect of his case after those letters that he wrote a bit of disappointment and a little bit of anger. However, he could not give up easily from Britain. He knew that the greatest support for the success of the Arab case came from Britain and that support would come from this state. At this point, his father was writing letters filled with advice and he was trying to direct his politics in London. So Sheriff Hussein in a letter to Faisal who had depressive days tried to influence the politics of Faisal in London;

\footnotetext{
${ }^{48}$ Evans, ibid., s. 225; The idea that the Arabs were betrayed was going to be spoken even higher in the years after the war. In 1943, King Abdullah confessed that they made two mistakes in the independence movement they called the Arab Revolution. The first was to emphasize that the Britain was very much to rely on, the second was to think that the Arab people and leaders would be in unity and solidarity in order to achieve common goals. Orhan Koloğlu, Lawrence Efsanesi, Yeditepe Pbl., İstanbul, 2016, s. 106.

${ }^{49}$ FO. 608/92, No: 18904, 21 Eylül 1919.

${ }^{50}$ Sheriff Hussein and Sir Henry Mcmahon had a mutual agreement about the post-war future of the Arab lands, the first of which was written by Sharif Hussein on 14 July 1915 to McMohan and continued until March 1916.

During this period, a total of 10 letters were written between the two parties. Although these letters were placed in front of Lloyd George himself by Faisal after the war, Lloyd George would not claim that these would be the result of a treaty between the two sides, and he would not consider the issues mentioned in the letters. Fort he content of the letters see Ali Karakaya, Milli Mücadele'de Manda Sorunu ve Harbold ve King-Crane Heyetleri, Başkent Pbl., Ankara, 2001; Sharif Hussein's son, Abdullah, said in a report about these letters from Mr Storrs, Secretary of State for Britain, who served as the Egyptian Consulate General in Egypt as" Great Britain is ready to help in every area to support the Arab revolt..." and he stated that the contacts between the British authorities and the Arabs took place as correspondence with Mcmohan. For the promises given to the Arabs in the letters and the implications of these words on the Arabs see King Abdullah, Biz Osmanlı'ya Neden İsyan Ettik, 9. Baskı, Klasik Pbl., İstanbul, 2013, pp. 95-97.

${ }^{51}$ Allawi, ibid., p. 310.
} 
"... If you consider how you went to Europe and how your opponents accept you, you will understand that we only need to know England. For that reason, you should negotiate onwly with Britain. We do not need the other governments. This is the basis of our policy. I command you as your father and your chief",52.

With the help of these letters from his father, in order to show that he did not intend to give up his case, Faisal wrote a letter to Lloyd George on October 9, 1919, asking once again to break the agreement with France and if not, at least to delay the withdrawal. Lloyd George, in a letter to Faisal's request, said that Britain had promised an Arab kingdom, including Damascus, Hama, and Aleppo, to Sheriff Hussein, but that the French had ambitions along the coast in the western part of these cities, and that it had previously been reported to Sheriff Hussein and he asked Faisal to recognize the British-French consensus on Syria's evacuation. Lloyd George further stated that this would help the Arabs achieve freedom and demanded that the best way to follow the Arabs would be to continue working friendly with Britain and France for the execution of this resolution. In any case, Lloyd George was asking for Faysal to accept a British French agreement and to immediately start negotiations with France for new arrangements on Syria. Those statements in Lloyd George's letter meant the failure of Faisal's policy against the French ambitions in London. In spite of months of persuasion, their request from British officals not to leave them alone with France did not work. As Faisal who was very angry and well worn was making preparations for his return to Syria, Clemanceau himself would write a letter in order to appease him. In the letter, Clemanceau stated that their aim was to help them, not to disrupt Syria and to change its borders at this point, he did not forget to guarantee the political future of Syria for Arabs and Faisal $^{53}$.

Faisal who evaluated the withdrawal of the British from the region as a major disaster for the Arab world and connected the whole strategy to the presence of Britain in the region, he planned to get the support of the American Government on the issue of mandate, but he failed in this regard ${ }^{54}$. Faisal would then return to Paris with enforcement of the British to deal with Clemanceau on the emerging situation in Syria ${ }^{55}$.

As a result of long talks that were tense and dissappointing for Faisal, The British government, especially after Lord Curzon and General Allenby's special efforts would succeed in convincing Faisal to go to Paris to discuss the new situation that emerged with the withdrawal of Britain from Syria and to make new arrangements ${ }^{56}$. In this way, Britain while taking hands from Syria with diplomatic maneuvers left Faisal alone with France on this issue.

\section{Conclusion}

By the end of 1919, Faisal left London with a great disappointment. It was obvious that he was angry. As a result of the negative results of the negotiations in London, in a period when serious unrest began to emerge slowly in his country, his attempt to agree with Clemanceau in Paris would bring deep and endless changes in the history of the Near East and

\footnotetext{
${ }^{52}$ FO. 608/92, No: 14426, 26 September 1919.

${ }^{53}$ Umar, ibid., pp. 381-382; Evans, ibid., p. 226.

${ }^{54}$ Because Faisal began to think that the annulment of the British-French consensus on Syria, especially the SykesPicot Treaty, could only be possible with the United States at a time when he was out of hopes about Britain. Öke, ibid., p. 314.

55 The British representative in Cairo, Meinertzhagen, in relation to the effects of the agreement on Faisal said as follows "The treaty was very unpleasant for him. But the attitude of the British authorities left him little choice, and he was handed over to the French." Allawi, ibid., p. 327.

${ }^{56}$ İbid., p. 311.
} 
the political future of Faisal. However, this process would not be as easy as expected, and it would cause conflicts between French and Arab troops in many parts of Syria ${ }^{57}$.

By the end of 1919, when the Near East was entering a new year, the region had still endless uncertainties. It was now clear that Faisal's attempt to agree with the France by request of Britain for peace would never bring peace and tranquility for any Arab who wished independence. But when Faysal set foot in Damascus in the early days of January 1920, he believed that he was still very useful for the sake of Syria's independence during the months he spent in Europe, and that he had reached an agreement with the French on a good ground at least in the recognition of Syria as a state. However, Damascus would meet him in a way that he never expected. The idea that prevailed in Damascus was that Faysal had betrayed the Arab cause, in agreement with the French. This was enough to affect Faysal deeply. Later on, he met with Arab tribal leaders and notables in Damascus and in many other parts of Syria, in an effort to raise public opinion by trying to explain how useful his work in London and Paris was for the future of Syria.

According to the agreement with Faysal, as the French troops began to be seen in Syria from 1920 onwards, the events in Syria had become even more inevitable. In particular, in March 1920, the Syrian Congress declared the independence of Syria and a similar initiative in Iraq immediately after that, was to be interpreted as a rebellion of the Arabs against them.

When they came together in San Remo in April 1920 to determine the principles of the peace treaty that Britain and France would sign with the Ottoman Empire, it was seen that the works in Syria and Iraq was complicated in the Near East. But even this would not allow Britain and France to abandon the attempt to shape the Near East according to their own interests, rather than according to the wishes of the people of the region, it was decided to give the French mandate of Syria under the League of Nations in San Remo, in the same way, the decision to leave Iraq under British mandate rule would be taken. These decisions were sort of an answer of the Allies against nationalist Arab revolts in Syria ${ }^{58}$.

Although it was known that it would not bring any solution to the problem of the Near East, invasion of Damascus by French with the approval of Britain and terminationg Faisal admistration and expelling him from Damascus would lead Faisal to go to LOndon and apply for being a king to another country ${ }^{59}$. While the British administration strived for his appointment as the king of Iraq, they would allow his brother Abdullah to be the king of Jordan which would be formed on the territory of Syria and Iraq. With the words of British diplomats, there was a process full of tricks in the region against $\operatorname{Arabs}^{60}$.

Undoubtedly, in an environment of political uncertainties in the region, the unrest that had already existed in the Near East with unending conflicts, it would cause an important part of the Arabs to the look with sympathy to the Turkish National Movement which was under the leadership of Mustafa Kemal in Anatolia. This sympathy carried the support and

\footnotetext{
${ }^{57}$ John D. Grainger, Suriye için Savaş 1918-1920, Tarih Kuram Pbl., Transl. Dr. Özer Bostanoğlu, İstanbul, 2015, p. 280, With the beginning of the withdrawal of the British, on 27 November 1919 in Aleppo, the madrasa students made a demonstration against the division of the country. They walked in the streets and read Arabic manifestos at government Office. Street demonstrations would continue in Aleppo in the following days. Umar, ibid., p. 382.

${ }^{58}$ Seda Altuğ, "Suriye Arap Milliyetçiliğinde Vatan ve Suriyelilik (1919-1939)", İstanbul Üniversitesi Siyasal Bilgiler Fakültesi Dergisi No: 39, October 2008, p. 78.

${ }^{59}$ Hadiye Yılmaz, "Mustafa Kemal-Emir Faysal Antlaşması ve Milli Mücadele Döneminde Suriye ve Irak”, CTAD, Year 10, Number. 20, Fall 2014, p. 297.

${ }^{60}$ Öke, ibid., p. 324.
} 
Resul YAVUZ

developments that would lead to a revolt in Syria and Iraq, It would conduce the British and French to revise their difficult to implement policies on the region

\section{REFERENCES}

\section{A-ARCHIEVE DOCUMENTS}

\section{1- Public Record Office (Britain National Archieve)}

\section{Foreign Office Records}

FO. 608/92. No: 1551, 1670, 1694, 1988, 2235, 2478, 2283, 5700, 6816, 10466, 13156, 14426, 15461, 18804, 18904.

\section{2- PERIODICALS}

\section{Magazines}

İstanbul Üniversitesi Siyasal Bilgiler Fakültesi Dergisi

CTA Dergisi

\section{B- POSTGRADUATE AND DOCTORAL THESIS}

DAVULCU, Mehmet, Faysal Döneminde Türkiye-Suriye Illişkileri (1918-1920), (Unpublished postdraduate thesis) Ankara Üniversitesi, Türk İnkılâp Tarihi Enstitüsü, Ankara, 2007, p. 82.

KILINÇKAYA, Mehmet Derviş, Arap Milliyetçiliği ve Milli Mücadele'de Türkiye-Suriye İlişkileri (30 Ekim 1918-21 Temmuz 1921), (Unpublished Doctoral Thesis), Hacettepe Üniversitesi, Atatürk İlke ve İnkılâpları Enstitüsü, Ankara, 1992, p. 121.

\section{C-BOOKS AND ARTICLES}

\section{Books}

ABDULLAH (Kral), Biz Osmanlı'ya Neden İsyan Ettik, 9th Ed., Klasik Pbl., İstanbul, 2013.

ALLAWI, Alı. A., Irak Kralı I. Faysal, Transl. Hakan Abac1, Türkiye İş Bankası Pbl., İstanbul, 2016.

ANTONiUS, George, The Arap Awekening, Khayet's College Book Cooperative, Beyrut, 1989.

BELL, Gertrude L., Mezopotamya'da 1915-1920 Sivil Yönetimi, Transl. Vedii İlmen, Yaba Pbl., 2004.

EVANS, Laurance, Türkiye'nin Parçalanması ve ABD Politikaları (1914-1924), Örgün Pbl., İstanbul, 2003.

GEORGE, David Lloyd, Memoirs Of The Peace Conferance, Cilt. II, Yale University Press, New Haven, 1939.

GRAİNGER, John D., Suriye için Savaş 1918-1920, Tarih Kuram Pbl., Transl. Dr. Özer Bostanoğlu, İstanbul, 2015, p. 280, 
GÜZTOKLUSU, Murat, Özdemir Bey’in Filistin-Suriye Kuvva-i Milliyesi ve Elcezire Konfederasyonu, Bengi Pbl., İstanbul, 2010.

HAYDAR, Rüstem, Mudhakarrat Rüstem Haydar, ed. Nejat Fathi Safwat, Al Dar alArabiyalil Mawsou'at Beyrut, 1988.

HELMREICH, Paul C., Sevr Entrikaları, Büyük Güçler, Maşalar, Gizli Antlaşmalar ve Türkiye'nin Taksimi, Transl. Şerif Erol, Sabah Pbl., İstanbul, 1996.

KARAKAYA, Ali, Milli Mücadele'de Manda Sorunu ve Harbold ve King-Crane Heyetleri, Başkent Pbl., Ankara, 2001.

KOLOĞLU, Orhan, Lawrence Efsanesi, Yeditepe Pbl., İstanbul, 2016.

LANSING, Robert, The Big Four and Others Of The Peace Conferance, Hutchinton, Londra, 1922.

MACMILliAN, Margaret, Paris 1919, (1919 Paris Barıș Konferansı ve Dünyayı Değiştiren Altı Ayın Hikâyesi), Transl. Belkıs Dişbudak, ODTÜ Pbl., Ankara, 2004.

ÖKE, Mim Kemal, Siyonizm ve Filistin Sorunu (1880-1923), 2nd Ed., K1rmızıkedi Pbl., İstanbul, 2011.

UMAR, Ömer Osman, Osmanlı Yönetimi ve Fransız Manda İdaresi Altında Suriye (19081938), AAM, Ankara, 2004.

TOLON, Ahmet Hurşit, Birinci Dünya Savaşı Strasında Taksim Antlaşmaları ve Sevr'e Giden Yol, AAM, Pbl., Ankara, 2006.

\section{Articles}

ALTUĞ, Seda, "Suriye Arap Milliyetçiliğinde Vatan ve Suriyelilik (1919-1939)", İstanbul Üniversitesi Siyasal Bilgiler Fakültesi Dergisi No: 39, October 2008.

YILMAZ, Hadiye, "Mustafa Kemal-Emir Faysal Anlaşması ve Milli mücadele Döneminde Suriye ve Irak", CTAD, year 10, Volume. 20, Fall 2014. 